Published in the Journal of Bahá'í Studies Vol. 4, number 2 (1991)

(C) Association for Bahá'í Studies 1991

\title{
Women in Art
}

\author{
Anne Gordon Atkinson
}

\begin{abstract}
Though creativity has often been associated with women, historically and in the present there have been many impediments to achievement by women in art. Often relegated to the role of the "muse," women have been expected to inspire men's creativity but not develop their own. Household responsibilities, the rearing of children, poverty, and lack of education, support, and encouragement have been among the reasons there have been few "great" women artists. Often work by women was never discovered, was published or presented anonymously, or was credited to a male. The Bahá'í writings state that women should receive equal opportunities for education, should participate in all avenues of human endeavor, and should become proficient in the arts and sciences. Men are called upon to affirm that the capacity of women is equal to and even greater than theirs, in order to foster the development of women. In a world in which both sexes are free to express their creativity, great advances will be made.
\end{abstract}

\section{Résumé}

Bien que des liens étroits se soient souvent développés, auf il des âges, entre la créativité et les femmes, que ce soit au cours de l'histoire ou même de nos jours, de nombreux obstacles ont empêché bien des femmes de parvenir à la consécration artistique. Fréquemment reléguées au role de muse, l’on attendait des femmes qu'elles inspirent la créativité masculine plutôt que de laisser cours à leur propre inspiration. Qu'il s'agisse de responsabilités familiales, de l'éducation des enfants, de la pauvreté et de 1'absence d'éducation, de soutien ou d'encouragement, de nombreuses raisons expliquent qu'il y ait eu peu de grands artistes féminins. Dans bien des car les oeuvres de femmes restaient dans l'ombre, n'étaient publiées ou présentées que de manière anonyme, ou étaient attribuées a un homme. Les Écrits bahá'ís indiquent que les femmes devraient béneficier des mêmes avantages que les hommes en ce qui a trait a l'éducation, devraient prendre part à tout léventail des activités humaines et devraient exceller dans les domaines des arts et des sciences. Aux hommes incombe la responsabilité d'affirmer très haut que le talent des femmes est non seulement égal au leur mais qu'il leur est aussi supérieur. Ce n'est qu'ainsi que pourra s'affirmer le talent féminin. Et dans an monde où les deux sexes auront toute liberté d'exprimer leur créativité, les progrés seront phénoménoux.

\section{Resumen}

Aunque la creativi dad frecuentemente se ha asociado con la mujer, históricamente y en el presente han habido muchos impedimentos al logro de la mujer en el arte. Frecuentemente reducida al rol de "musa," la mujer ha estado supuesta de servir de inspiración a la creatividad del hombre, quedando al margen de poder ella desarrollar su propia creatividad. Las responsabilidades caseras, la cría de los nifsos, Ia pobreza, y lafalta de educación, de apoyo y de estimulo, son algunas de los razones por lo cual han habido tan pocas "grandes" mujeres artistas. Ocurre que muchas obras hechas por mujeres nunca fueron descubiertos, fueron publicadas o presentadas anónimamente, o se les atribuyó a un hombre. Los escritos bahá'is declaran que la mujer debe recibir iqualdad de oportunidad en la educación, debe participar en todos los campos adelanto, y lograr habilidad en las artes y ciencias. El hombre es llamado a constar que la capacidad de la mujer es igual y aun mayor que el de ellos, fomentando así el desarrollo de la mujer. Llegado un mundo en donde ambos sexos obtienen libertad para expresar su creatividad, habrán grandes adelantos.

$\mathrm{W}$ oman traditionally has played the role of the muse-the one to inspire (male) creativity, or the one whose creative acts were limited to procreation and crafts or hobbies within the home. She was certainly not encouraged to develop creative gifts to the point of being unavailable to those who needed and depended on her, or she was labeled "selfish" or "eccentric" if she did.

In an essay entitled "From Muse to Heroine: Toward a Visible Creative Identity," Anne Griswold Tyng describes the fate of one creative woman:

Alma Schindler (1879-1964) "the most beautiful girl in Vienna," had ability she might have developed as a 
composer; at twenty-two she married Gustav Mahler, win was forty-one and already a famous composerconductor. On the eve of the marriage, Mahler wrote to Alma:

How do you picture the married life of a husband and wife who are both composers? Have you my idea how ridiculous and, in time, how degrading for both of us such a peculiarly competitive relationship would inevitably become1 What will happen if, just when you're 'in the mood', you're obliged to attend to the house or to something I might happen to need? . . . You must become 'what I need' if we are to be happy together, i.e., my wife, not my colleague.

Alma agreed to Mahler's demands. But, married three years, she wrote in her diary: "It came to me suddenly that I am living what only appears to be a life. I hold so much inside of me, I am not free-I suffer-but I don't know why or what for.” For his part, Mahler was unable to compose without her presence to nourish an inspire him. (Architecture 172-73)

After Mahler died, Alma became the lover of painter Oskar Kokoschka and eventually married architect Walter Gropius, from whom she was divorced and then married poet/novelist/playwright Franz Werfel. She had affairs with other noted men. "Nine published songs remain as fruits of her own creativity (Tyng, "From Muse to Heroine” 173). Tyng further notes:

The steps from muse to heroine are accomplished by very few. Many women trained as architects marry architects. No longer the women behind the man, the woman architect in partnership with her husband may nevertheless be barely visible beside (or slightly behind) the hero.

The man's creative output and recognition are often inflated; credit by the partner wife is frequently omitted. This situation is compounded by the woman's projection of her own potential for visible achievement onto the real-life man who acts and is perceived as the hero-animus. The two are further bound in work and love by the man's projection of his anima or generative source of creativity onto his real-life partner. ("From Muse to Heroine” 176-77)

How do we restore, create, and sustain a female presence in the arts? How do we nurture ourselves as women artists? It is only recently that scholars, historians, aesthetic theorists, art critics, and artists themselves have looked at and taken seriously the voice and role of women in art. Half the voice of humanity has been suppressed, ignored, undeveloped, unheard.

When we turn, for example, to literary history, we find no texts in the Old English period that have definitively been written by women, hardly any works by medieval women, and very few by Renaissance women. No doubt some women wrote, but their works perhaps were not considered worth saving, have been handed down or published anonymously, or were never discovered. We know that it is likely, however, that most women did not write because they did not have access to the education or social acceptance that would facilitate such activity and because they were confined to the home with all that required of them, were constrained by cultural definitions of femininity, had little experience in public life and no expectation of an audience that would encourage and foster their creativity.

Those who did write (or create works in any artistic field) were generally spiritually unusual—solitary visionaries or rebels against social conventions. They were also distinctively concerned with the problems creativity posed for women and plagued by the images of women that men had constructed for them. They often had to confront the misogyny of male theologians who sought to censure and silence them. As well, they had to confront an ideal of courtly life that glamorized and glorified them in ways that were at times problematic.

The Anglo-Saxon culture that predated Christianity in England was oblivious of or hostile to women. One of the few lyrics attributed to a woman from this period—a piece called "The Wife's Lament" c. 900)—begins with a complaint:

I make this song sadly about myself, about my life. I a woman say

I've been unhappy since I grew up.

(Norton Anthology 5)

In Beowulf, the major epic of the age, women are objects of exchange, servants to men, monsters, or mothers of monsters. Embedded in even the most chivalric texts are images of women as monsters or witches; any 
beautiful lady, these romances hint, might be a sorceress. Behind even the highest praise of women often were implied criticism and secret hostility.

As the religious and civic upheavals of the seventeenth century created new belief systems, urbanization, and the ascendancy of science and rationalism, women's lives and views of women began to change. Many women lamented what one expressed-the fact that men "refuse to let us know / what sacred Science doth impart" (Norton Anthology 47), and novelist Sarah Fielding explained in a preface to one of her books published in 1744, "Perhaps the be excuse that can be made for a woman's venturing to write at all, is that which really produced this book; distress in her circumstances: which she couldn't so well remove by any other means in her power" (Norton Anthology 49-50). With the abolition of the patronage system, women began to seek publication on the own, though many were financially dependent on male relatives. Certainly in many cases hostility towards men was felt, since men had the power to prevent a woman from pursuing creative endeavors. Lady Winchilsea, born in 1661, writes with indignation about the position of women as defined by men:

\author{
Alas! a woman that attempts the pen, \\ Such a presumptuous creature is esteemed, \\ The fault can by no virtue be redeemed. \\ They tell us we mistake our sex and way; \\ Good breeding, fashion, dancing, dressing, play, \\ Are the accomplishments we should desire; \\ To write, or read, or think, or to enquire, \\ Would cloud our beauty, and exhaust our time, \\ And interrupt the conquests of our prime, \\ Whilst the dull manage of a servile house \\ Is held by some our utmost art and use. \\ (Quoted in Woolf, A Room of One's Own 62)
}

There emerged a new image of woman, the satiric portrait of the female artist that constituted a reaction against their growing visibility. Attack frequently explained why many women were unable to write, publish, or produce artworks, and those who did, felt it necessary to apologize or justify their efforts. "Puritan scorn for socalled scribbling women is aptly) demonstrated by Thomas Parker's 1650 condemnation of his sister: 'Your printing of a book beyond the custom of your sex doth rankly smell' "(quoted in Norton Anthology 52).

Female erudition was satirized. In 1645, the American Puritan John Winthrop bemoaned the lot of a woman who had "fallen into a sad infirmity, the loss of her understanding, and reason, which had been growing upon her diverse years, by occasion of her giving herself wholly to reading and writing, an written many books" (quoted in Norton Anthology 52-53).

Toward the end of the century Samuel Johnson assumed that creativity and femininity were contradictory terms when he compared a woman preacher to dancing dog, or when he condemned portrait painting as improper in women because "public practice of any art. . . staring in men's faces, is very indelicate in a female" (quoted in Norton Anthology 53).

Taking a look at why it has been so hard for women to achieve success as artists, we see that society has not sanctioned the kind of dedication it takes for a woman really to advance in an art form. In her book The Obstacle Race: The Fortunes of Women Painters and Their Works, Germaine Greer examines some of the reasons behind this reality. She notes that most women who became famous as painters were related to better-known male painters. The participation of these women in the graphic arts "was probably a filial and submissive response to the family environment and family pressure. . . . Women artists before the nineteenth century seldom expressed their own creativity: they imitated the modes of self-expression first forged by integrated, self-regulating (male) genius, most often when they were already weakened by eclecticism and imitation (13). Greer further comments that art history "abounds with the names of sisters who worked with or for their brothers, not only painting for them, but copying and engraving their works, travelling with them and keeping house for them (Obstacle Race 28).

To Greer, "To be truly excellent in art was to be de-sexed, to be a woman only in name, to inhabit a special realm that no other women could enter, to be separated from all other women, or it was to express true femininity in grace, delicacy, sweetness and so forth, and be condemned to the second rank" (Obstacle Race 75). Greer also looks at the manifestations of the oppression for women artists and its pathology, noting

the signs of self-censorship, hypocritical modesty, insecurity, girlishness, self- deception, hostility towards one’s fellow strivers, emotional and sexual dependency upon men, timidity, poverty and ignorance. All 
these traits of the oppressed personality are only to be expected; the astonishing and gratifying thing is that so many women conquered all of these enemies within some of the time, most often when they were young, before marriage and childbirth or poverty and disillusionment took their toll. (Obstacle Race 11)

Anne Garlin Spenser, an American social reformer, comments wryly, "when her biographer says of an Italian woman poet, 'during some years her Muse was intermitted', we do not wonder at the fact when he casually mentions her ten children” (from the author's notes).

Reminded constantly of their inadequacies and the impediments to creativity posed by lack of education, domestic preoccupations, and the resentment that confinement breeds, women expressed such sentiments as the following verse by Mary Oxlie:

Perfection in a woman's work is rare;

From an untroubled mind should verses flow;

My discontents make mine too muddy show;

and hoarse encumbrances of household care,

Where these remain the Muses ne'er repair.

(Norton Anthology 56)

Anne Bradstreet, a well-educated, prolific writer of the Puritan period in America and who was also the mother of eight children, refers to her "foolish, broken, blemished Muse," a talent "made irreparable" by nature, for "men can do best, and women know it well" (Norton Anthology 60). But at the same time she allows herself a flash of anger and independence:

I am obnoxious to each carping tongue

Who says my hand a needle better fits

if what I do prove well, it won't advance,

They'll say it's stolen, or else it was by chance.

(Quoted in Norton Anthology 60)

When her brother-in-law arranged without her knowledge to have her book The Tenth Muse printed in London, he wrote a foreword carefully explaining that her verse was "the work of a woman, honoured and esteemed where she lives, for. . . her exact diligence in her place, and discrete managing of her family occasions, and. . . these poems are but the fruit of some few hours, curtailed from her sleep and other refreshments" (quoted in Norton Anthology 60).

It was not until Mary Wollstonecraft's book A Vindication of the Rights of Women came out in 1792 that misogynist images in literature were criticized. Her impassioned plea against the miseducation of women and her argument for female political, economic, and legal equality fell on deaf ears for the most part. She was denounced as a "hyena in petticoats" and a "philosophical wanton" (Norton Anthology 138).

It is no wonder such figures as Táhirih (Qurratu'l-'Ayn), a Persian poet and the first woman in Iran to discard the traditional veil, was strangled in 1850 and thrown into a well. She was the victim of religious persecution as well as societal denunciation of women (Root, Táhirih). Or that the American poet Emily Dickinson hid away in her father's house and never married, hiding 1,776 poems that did not find an audience in her lifetime (Norton Anthology 839).

Maria Edgeworth, writing both an attack on and a defense of "literary ladies" in 1795, describes some of the problems such a calling presents:

Literary ladies will, I am afraid, be losers in love as well as in friendship, by their superiority.-Cupid is a timid, playful child, and is frightened at the helmet of Minerva [the goddess of wisdom]. It has been observed, that gentlemen are not apt to admire a prodigious quantity of learning and masculine acquirements in the fair sex-we usually consider a certain degree of weakness, both of mind and body, as friendly to female grace. I am not absolutely of this opinion, yet I do not see the advantage of supernatural force, either of body or mind, to female excellence. (Quoted in Norton Anthology 190)

Despite the fears that education and creative activity might alienate men and lead to other hardship and disaster, a great clamoring for emancipation was raised. We have the brilliant speeches by Sojourner Truth, for example, who spoke out for the cause of women's suffrage, racial equality, and spiritual themes. Here, art took the form of oral tradition-luckily preserved in part. 
Illiterate and born into slavery, Sojourner Truth spoke for oppressed people with humor and courage in such speeches as “Ain’t I a Woman?”:

Well, children, where there is so much racket there must be something out of kilter. I think that 'twixt the negroes of the South and the women of the North, all talking about rights, the white men will be in a fix pretty soon. But what's all this here talking about?

That man over there says that women need to be helped into carriages, and lifted over ditches, and to have the best place everywhere. Nobody ever helps me into carriages, or over mud-puddles, or gives me any best place! And ain't I a woman? Look at me! Look at my arm! I have ploughed and planted, and gathered into barns, and no man could head me! And ain't I a woman? I could work as much and eat as much as a man — when I could get it—and bear the lash as well! And ain't I a woman? I have borne thirteen children, and seen them most all sold off to slavery, and when I cried out with my mother's grief, none but Jesus heard me! And ain't I a woman?

Then they talk about this thing in the head; what's this they call it? [Intellect, someone whispers.] That's it, honey. What's that got to do with woman's rights or negro's rights? If my cup won't hold but half a pint, and your's holds a quart, wouldn't you be mean not to let me have my little halfmeasure full?

Then that little man in black there, he says women can't have as much rights as men, 'cause Christ wasn’t a woman! Where did your Christ come from? Where did your Christ come from? From God and a woman. Man had nothing to do with Him.

If the first woman God ever made was strong enough to turn the world upside down all alone, these women together ought to be able to turn it back, and get it right side up again! And now they is asking to do it, the men better let them.

Obliged in you for hearing me, and now old Sojourner ain’t got nothing more to say. (Quoted in Norton Anthology 253)

The twentieth century has seen a much greater proliferation of women artists as great social changes occurred and the world experienced the profound impact of wars between nations, technological advancement, and greater numbers of women in the work force. Still, writers sensitive to the plight of women in general and in the creative fields in particular felt a need to voice the ramifications of inequality.

Virginia Woolf, hypothetically speculating on whether Shakespeare's sister could have produced the body of writing that he did, explored in A Room of One's Own the necessary conditions for a woman to be able to create. Woolf was one of the first to articulate the great difficulty women have in obtaining the necessary freedom from household details and economic cares in order to justify a calling such as writing. Here, she considers the moment when the middle-class woman began to write as a "change of greater importance than the Crusades or the War of the Roses" (Woolf, A Room 68). Her essay reminds us that our times are not so different from Shakespeare's in some ways - women are for the most part still bound to fulfil expectations that prohibit development and creativity, and they still lack both the physical space and the financial means to be able to produce work of consequence. "Intellectual freedom," says Woolf,

depends upon material things. Poetry depends upon intellectual freedom. And women have always been poor, not for two hundred years merely, but from the beginning of time. Women have had less intellectual freedom than the sons of Athenian slaves. Women, then, have not had a dog's chance of writing poetry. (A Room 112)

Woolf herself, an accomplished professional writer with a supportive husband and literary circle, asks in her diary, "Is the time coming when I can endure to read my own writing in print without blushing - shivering and wishing to take cover?" (Woolf, A Writer's Diary 11). I think this speaks to the great fear of criticism and being vulnerably exposed that most women experience when engaged in creative work.

A 1971 article entitled "Why Have There Been No Great Women Artists?” came as a major shock to some, and its author Linda Nochlin forced readers to ask questions that most people had previously avoided. As well as insisting that we take a different look at the definition of a great artist, she pointed out that the soil wasn't very hospitable for the growth of women artists.

Ravenna Helson, who has examined creativity in women over time, notes that in the 1950s, "it was generally agreed that women were not sufficiently independent, assertive, ambitious, original, or abstract-minded to be creative. They were-and should be-more interested in their families than in fame or scientific advances” 
("Creativity in Women" 46). Gradually, because of the women's movement and other social trends, she says that "we realize that social roles have not been structured so that very many women would ever become high achievers" (“Creativity in Women” 46).

Helson goes on to explain that initiating change and being creative are manifestations of power-hence, in a patriarchal society, it is not seen as natural or appropriate for women to be creative, and to find images of feminine power, women often have to go to very ancient history or myth. Yet,

there is the persistent idea that creativity involves both masculine and feminine characteristics. One reason to be puzzled that there are "so few" creative women is that women have what we think of as creative interests-art, music, literature, religion. I suggest that women have these interests because they involve feeling and relationship, which women take seriously. But one reason they take feeling and relationship seriously is that they are dependent and often feel conflict about dependence. The same conflict over dependence that contributes to a girl's creative interest is also a factor that holds her back in actualizing her potential. (“Creativity in Women” 47)

Helson further describes the problems of identity that women have as creative persons-problems with establishing egalitarian intimate relationships, dealing with children, finding role models, and avoiding disadvantages in the world of work. Most women are more comfortable where there is a minimum of institutional credentialing, status, and bureaucracy, she says, and concludes, quoting Nancy Chodorow, "liberal sociocultural conditions, flexible arrangements, and congenial and challenging work" lead to a flowering of creativity in women (“Creativity in Women” 51).

The Bahá'í teachings, which emphasize equality of the sexes and the importance of the role of women in all arenas of life, pinpoint the revelation of Bahá'u'lláh as the cause behind the awakening of women and men to the need for full equality. Bahá'u'lláh says, "In this Day the Hand of divine grace hath removed all distinction. The servants of God and His handmaidens are regarded on the same plane” (quoted in Women 3).

'Abdu'l-Bahá explains that "woman has been denied the opportunities which man has so long enjoyed, especially the privilege of education” (Promulgation 75). He further states: “. . . in the estimation of God there is no distinction as to male and female" (Promulgation 133). Describing the past as a time when man has dominated, 'Abdu'l-Bahá speaks about the shifting of balance and predicts: "Hence the new age will be an age less masculine, and more permeated with the feminine ideals ... an age in which the masculine and feminine elements of civilization will be more properly [evenly] balanced" (quoted in Star of the West 3.3: 4 and Women 13).

The advancement of women is intimately linked with the Bahá'í Faith. 'Abdu'l-Bahá affirms that "the greatness of this wondrous Age will be manifested as a result of progress in the world of women. This is why ye observe that in every land the world of women is on the march, and this is due to the impact of the Most Great Manifestation, and the power of the teachings of God" (quoted in Women 22-23). And 'Abdu'l-Bahá issues a warning: “. . . the assumption of superiority by man will continue to be depressing to the ambition of woman, as if her attainment to equality was creationally impossible; woman's aspiration toward advancement will be checked by it, and she will gradually become hopeless. On the contrary, we must declare that her capacity is equal, even greater than man's" (Promulgation 76).

Of course, the realization of equality will not happen overnight. In terms of the art world we now have anthologies and exhibitions devoted to bringing to light women's works previously lost to history or ignored (though such works usually are not studied except in the context of Women's Studies, as if women are still considered a subspecies of humanity). There is also a National Museum of Women in the Arts in Washington, D.C. There is a movement to take seriously what was once ignored or criticized, to find that greatness where it existed and to celebrate it. But have we really changed the climate for women artists?

For many women, there are constant issues of self-esteem, fear of failure and fear of success, fear of criticism, and (worst of all) fear of eternal loneliness as we approach our education, career, creative work, and publication, exhibition, and performance. For a sex socialized to put others' needs before their own, independence and self-actualization can be very threatening.

Men, who are often denied access to the feeling and intuitive parts of themselves, are also held back from creative directions; many would-be artists are pointed towards more "practical" careers. It is no wonder that people (of either sex) who are actualizing their creative potential are viewed suspiciously and with a degree of envy or misunderstanding.

The Bahá'í writings are clear on the mandate for women, "She must become proficient in the arts and sciences and prove by her accomplishments that her abilities and powers have merely been latent” ('Abdu'l-Bahá, Promulgation 283). What will happen when she does this? War will cease, the Bahá'í writings predict, and the bird 
of humanity will fly toward a new apex with both wings equally developed. The male poet Rimbaud expressed it thus:

When the unending servitude of women is broken, when she lives by and for herself, when man — hitherto abominable-has given her her freedom, she too will be a poet! Women will discover part of the unknown. Will her world of ideas be different from ours? She will discover things strange and unfathomable, repulsive and delicious. We shall take them into ourselves, we shall understand them. ('The Poet” 204-5)

Perhaps the time is coming when women and men will understand each other, will be mutually supportive, will allow creativity to flourish and to enrich our communities. Women have much to offer to such a world.

\section{Works Cited}

'Abdu’l-Bahá. The Promulgation of Universal Peace: Talks Delivered by 'Abdu’l-Bahá during His Visit to the United States and Canada in 1912. Comp. Howard MacNutt. 2d ed. Wilmette, IL: Bahá'í Publishing Trust, 1982.

Greer, Germaine. The Obstacle Race: The Fortunes of Women Painters and Their Works. New York: Farrar, Straus, Giroux, 1979.

Helson, Ravenna. “Creativity in Women: Outer and Inner Views Over Time.” In Theories of Creativity. Mark A. Runco and Robert S. Albert, eds. Newbury Park, CA: Sage Publications, 1990.

Nochlin, Linda. "Why Have There Been No Great Women Artists?” excerpted from "Women in Sexist Societies: Studies in Power and Powerlessness.” Art News 69 (January 1971): 22-39.

Norton Anthology of Literature by Women. Sandra M. Gilbert and Susan Gubar, eds. New York: W. W. Norton, 1985.

Rimbaud, Arthur. “The Poet as Revolutionary Seer.” In The Modern Tradition. Richard Ellmann and Charles Feidelson, Jr., eds. New York: Oxford University Press, 1965.

Root, Martha. Táhirih the Pure. Rev. ed. Los Angeles: Kalimát Press, 1981.

Tyng, Anne Griswold. "From Muse to Heroine: Toward a Visible Creative Identity.” In Architecture: A Place for Women. Ellen Perry Berkeley, ed. Washington: Smithsonian Institution Press, 1989.

Women: Extracts from the Writings of Bahá'u'lláh, 'Abdu'l-Bahá, Shoghi Effendi, and the Universal House of Justice. Comp. Research Dept. Bahá’i World Centre. Thornhill, ON: Bahá’í Canada Publications, 1986.

Woolf, Virginia. A Room of One’s Own. New York: Harcourt, Brace and World, 1957. . A Writer's Diary. New York: Harcourt Brace Jovanovich, 1954. 